Resarch report

\title{
Dzierżoniów Town in the eyes of its residents - a study report
}

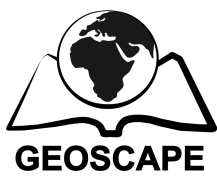

\author{
Andrzej Raszkowski ${ }^{1 *}$
}

${ }^{1}$ Wrocław University of Economics, Faculty of Economy, Management and Tourism in Jelenia Góra, 3 Nowowiejska

Street, 58 - 500 Jelenia Góra, Poland

*andrzej.raszkowski@ue.wroc.pl

\begin{abstract}
Dzierżoniów's residents definitely represent one of its most valuable resources. Its development and improvement of the generally approached life quality depends on their involvement in solving social and economic problems, their entrepreneurship and creativity. It should also be emphasized that the vast majority of surveyed residents are in favour of their city development. This phenomenon is based on the principle of mutual dependencies, i.e. the better the city functioning, the better living the conditions provided for its residents. On the other hand, the more active and involved the residents are the more effective is their support for the city development (e.g. by their involvement in NGOs' activities). The presented article was prepared based on the survey studies ordered by Dzierżoniów's Town Office and conducted in the period July-August 2013 which covered, among others, the city residents (422 respondents). The research was carried out within the framework of one of the stages in developing Dzierżoniów's Local Sustainable Development Strategy for the period 2014-2020. The purpose of the study is to discuss and assess the selected functional areas of Dzierżoniów Town (geographic environment, economy, technical infrastructure, social infrastructure, city management) based on its residents' opinions.
\end{abstract}

Key words: local development; Dzierżoniów; local community; city development strategy

Highlights for public administration, management and planning:

- survey has shown that residents are highly interested in development of their city

- the effect of residential support to development depends on the level of involvement of residents through various activities

Received: 2 Nov 2015 - Accepted: 1 Dec 2015

\section{Introduction and rationale}

The activities and projects focused on (local, regional) community life quality improvement represent major tasks which have to be carried out by the local government units (Raszkowski 2014, p. 197-198; Pike et al. 2006, p. 3-4). In this case life quality should be referred to as a multidimensional concept combining material aspects of life, such as e.g. the level of salaries, the availability of social and technical infrastructure facilities and also less measurable aspects referring primarily to the residents' general health condition, the sense of prestige resulting from living in a particular place or the experienced satisfaction of life, manifested in the possibilities for meeting individual, private and professional aspirations (Yuan et al. 1999, p. 3-4; 
Clark et al. 2010, p. 22). Residents represent the most important and valuable resource of any territorial unit. While analyzing this problem in a broader perspective it should be observed that sustainable socio-economic development of such unit depends, to a great extent, on human capital available in a given municipality, or rather on its quality (Blair, Carroll 2009, p. 145-153). The support of human capital development should be materialized in the form of numerous and diversified initiatives aimed at e.g. its quality upgrading and developing a consensus within a local community regarding the crucial development directions or projects implemented by the local government. The activities focused on such consensus strengthen the sense of local identity, as well as legitimize the operations performed by the local authorities (Kornblum 2011, pp. 131; Hague 2005, p. 4).
The population of Dzierżoniów has been in decline in recent years, similarly to the majority of local government units all over the country and also in the region. The number of residents decreased from 36100 in 2004 to 33372 in 2014. Having taken into account both the birthrate and the migration balance recorded in the city, the relatively stable number of residents may result from the inflow of population from other units to Dzierżoniów, which is a positive trend in the times of demographic turbulences and strengthens the city image as the potential location for permanent residence. One of the biggest threats is associated with young, production age people leaving the city and this particular problem should be discussed in more detail.
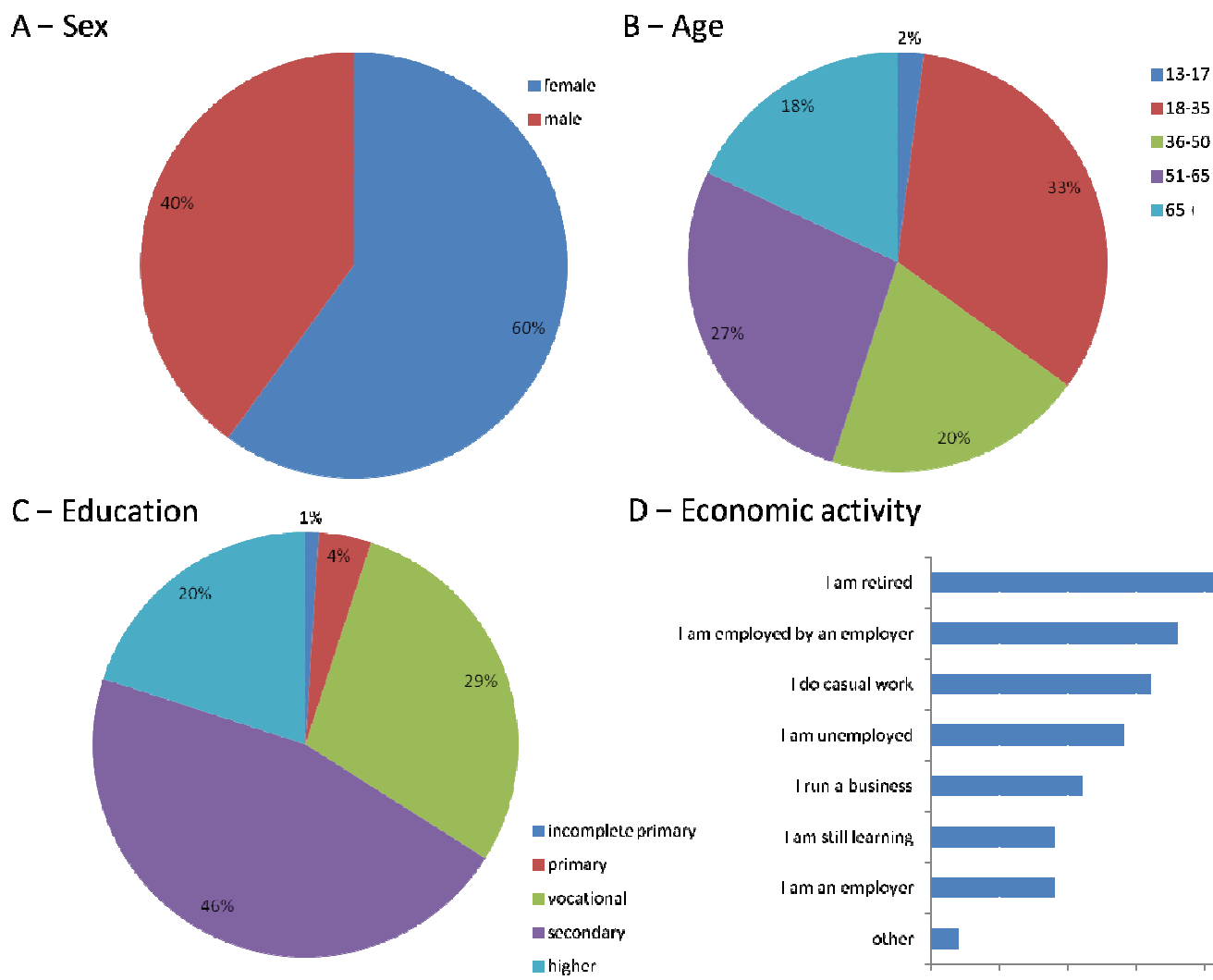

- Economic activity

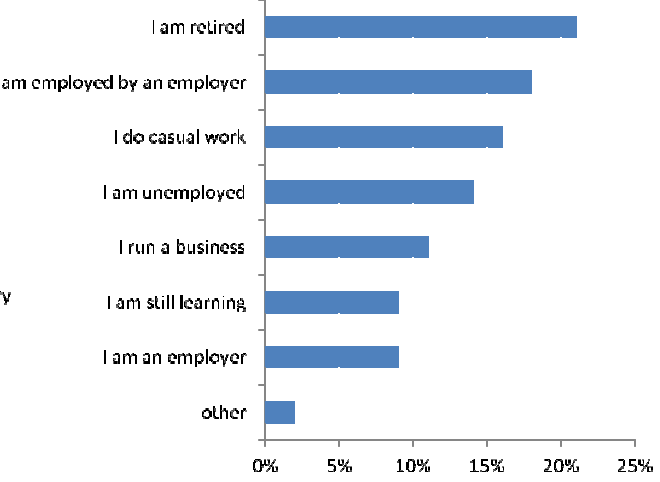

Fig. 1 - Structure of respondents. Source: author's survey. 
The presented study was prepared based on survey studies ordered by Dzierżoniów's Town Office and carried out in the period July-August 2013, which covered the following groups of respondents: the city residents $(422$ respondents), entrepreneurs (48 entities), NGOs' representatives (32 organizations), Town Office employees, the subordinate units and companies with the participation of Dzierżoniów municipality (203 people) (Fig. 1). Summarizing the analysis of respondents' structure it should be observed that women constituted the majority of respondents $(60 \%-40 \%)$, whereas the individuals aged 18-35 represented the most numerous age group (33\%), followed by those aged $51-65$ (27\%). The majority of respondents were characterized by secondary education (45\%), vocational (29\%) and higher (20\%). In terms of professional activity the largest group was represented by pensioners (21\%), employees $(18 \%)$ and those performing casual work (16\%). Later in the study the survey results, based on the answers provided by the respondents, will be analyzed. The research tool took the form of a survey questionnaire. All interviewers participating in the project were adequately trained in terms of both organizational and substantive matters. The above-mentioned research process represented one of the stages in the construction process of Dzierżoniów's Local Sustainable Development Strategy for the period 2014-2020 (Raszkowski 2013a, 2013c).

Residents, NGOs and business sector, apart from local government, constitute the inherent components and incentives for local development processes. The development oriented assessments and suggestions represent a valuable source of information for the entities responsible and involved in the local space development. The collected research results provide a demonstrative material (owing to their limited range) and also support local authorities and other stakeholders participating in the city development processes to undertake activities in response to the reported expectations and problems. Moreover, they can turn out helpful in establishing partnership relations between local government authorities and other local scene actors, thus becoming a part of an effective functioning of the local development strategy (Klasik 2002, p. 28-57; Strzelecki 2008, p. 78-119).

\section{Study area}

The town of Dzierżoniów (municipality) is located in south-eastern part of Lower Silesia region in the district of Dzierzioniów. The other local government units covered by the district are as follows: Bielawa, Pieszyce, Piława Górna (municipalities), Niemcza (urban-rural commune), Dzierżoniów, Łagiewniki (rural communes). The town is situated in Dzierżoniów valley, upon the river Piława, about $60 \mathrm{~km}$ from Wrocław, the capital of Lower Silesia. Sowie Mountains, Kiełczyńskie Hills and Ślęża Massif are located nearby Dzierżoniów, which results in higher tourist potential of the city. The municipality of Dzierżoniów is adjacent to Pieszyce and Bielawa municipalities as well as Dzierżoniów rural municipality. The city area is $20.07 \mathrm{~km}^{2}$. In terms of its communication system one can assume that the city is relatively well connected with major regional urban centres (Wrocław, Wałbrzych, Świdnica) and A4 motorway. At the same time Dzierżoniów remains the largest city in the district, with the seat of the Town Office, Dzierżoniów Commune Office (rural commune) and the District Office. It plays the role of a natural administration and service centre in the local and sub-regional (district) scale (Raszkowski 2013b).

The purpose of the study is to discuss and assess the selected functional areas of Dzierzoniów Town (geographic environment, economy, technical infrastructure, social infrastructure, city management) based on its residents' opinions.

\section{Results}

The presented survey results remain the component of a report constituting an integral part of Dzierżoniów's Local Sustainable Development Strategy for the period 2014-2020. The information presented in the report, apart from supporting the process of the city strategy development can also be approached as the compendium of knowledge about developmental preferences and the city situation assessment 
from the perspective of particular social and professional groups which co-create the town.

The survey results included in the report present a demonstrative material supporting local authorities and other stakeholders involved in the city development to undertake actions in response to its residents' expectations. The author would like to make a methodological comment explaining that if in the selected multiple choice questions the responses given do not add up to $100 \%$ it means that some of the respondents did not provide all the answers. Such situations, however, are quite rare and do not influence either the general results or conclusions presented on their basis. The professional approach and involvement of the Town Office employees in the research process should also be emphasized.

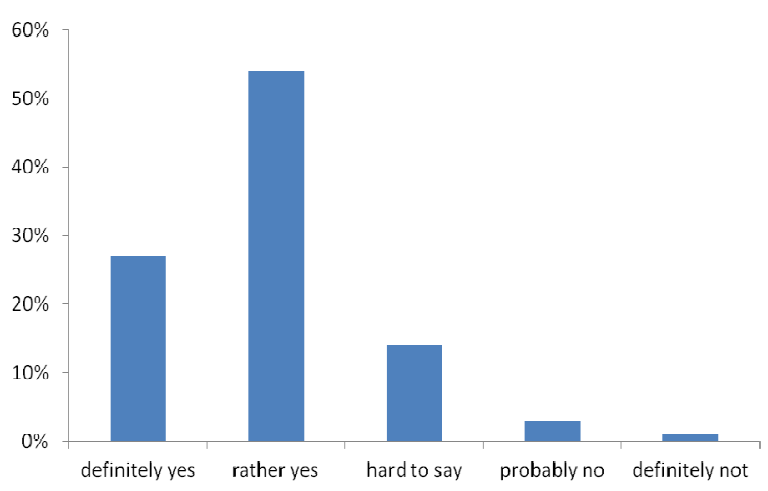

Fig. 2 - Do you care about Dzierżoniów development? Source: author's survey.

The city residents represent its important capital and the source of existence, therefore their opinions and comments should be considered as highly significant and with utmost attention. The vast majority of residents do care about Dzierżoniów's development (81\%), which is definitely a very positive sign for the future. Simultaneously, most of them (76\%) claim that the city has developed in recent years (Fig. 2). It confirms high efficiency of urban space management, which is even more valuable since the discussed years follow the global economic crisis dating from 2008.

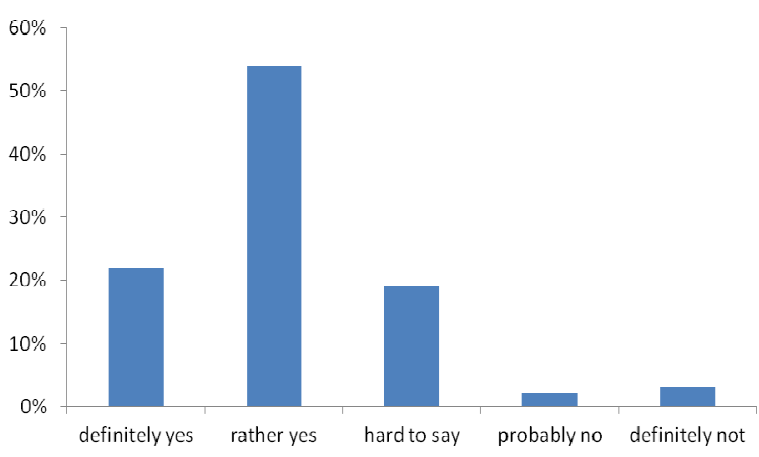

Fig. 3 - Has Dzierżoniów developed in recent years (2010-2013) in your opinion? Source: author's survey.

In case of social infrastructure assessment the educational opportunities for children and young people were ranked as best, to be followed by the possibilities for upgrading or changing qualifications by adults and access to public services - $71 \%, 60 \%$ and $54 \%$ of positive assessments respectively. Access to medical services was evaluated as the worst (33\%), similarly to the support for people in need of assistance (29\%) (Fig. 3).

The functional area of city management was highly evaluated. High levels of positive responses were recorded both in case of the Town Office functioning (77\%) and the activities carried out by the city authorities (63\%) (Figs. 4-8).

Bigger concerns are raised by the analysis of residents' involvement in the city life. As many as $49 \%$ of the respondents indicate not being involved in the city life. It has to be emphasized, however, that such situation is prevailing in the entire country and is not exclusively specific for Dzierżoniów. If the residents get involved at all it takes the form of their participation in city events (34\%) and based on the information provided by the local media (22\%) (Fig. 9). 


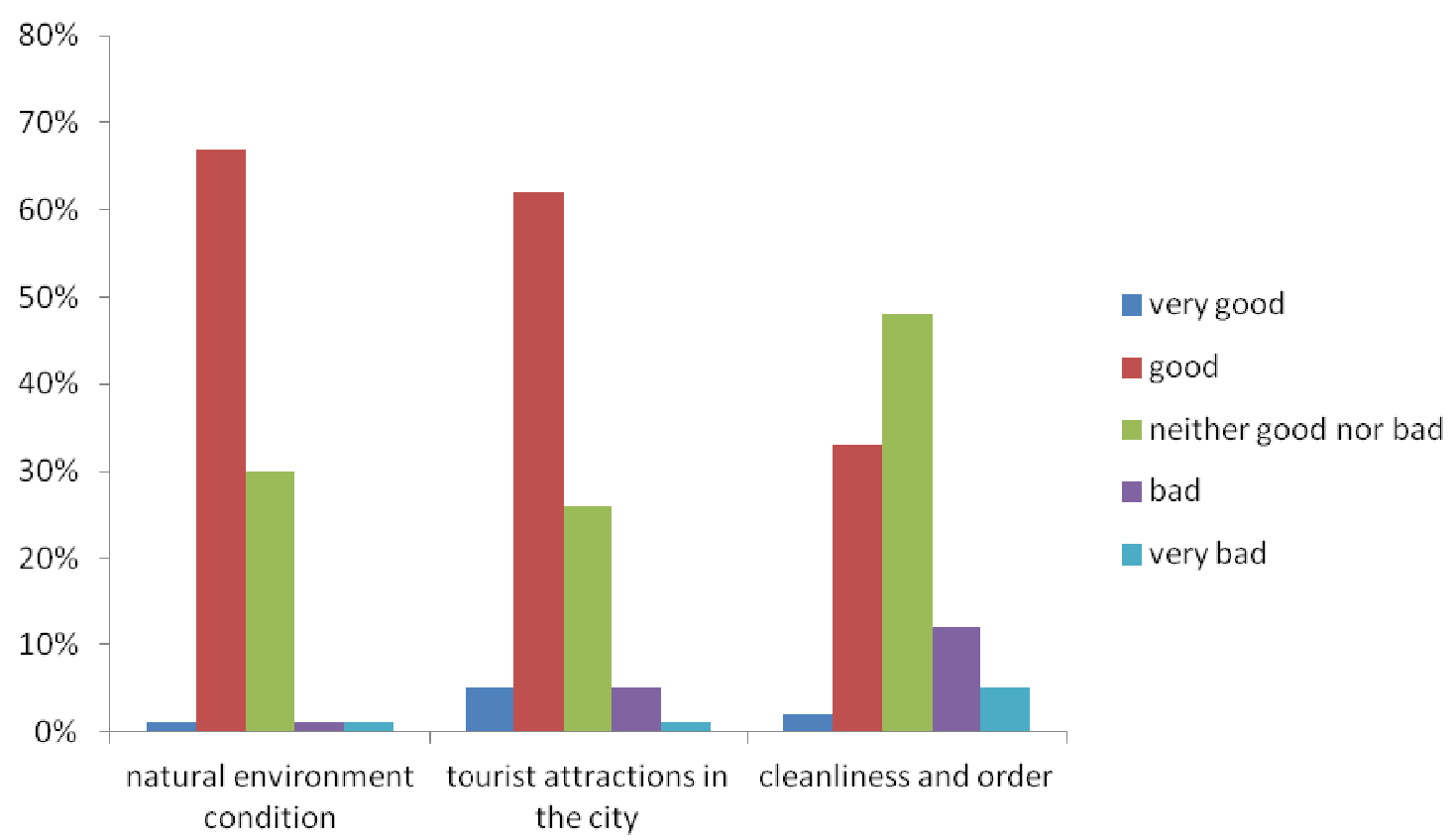

Fig. 4 - Geographic environment - functional area assessment. Source: author's survey.

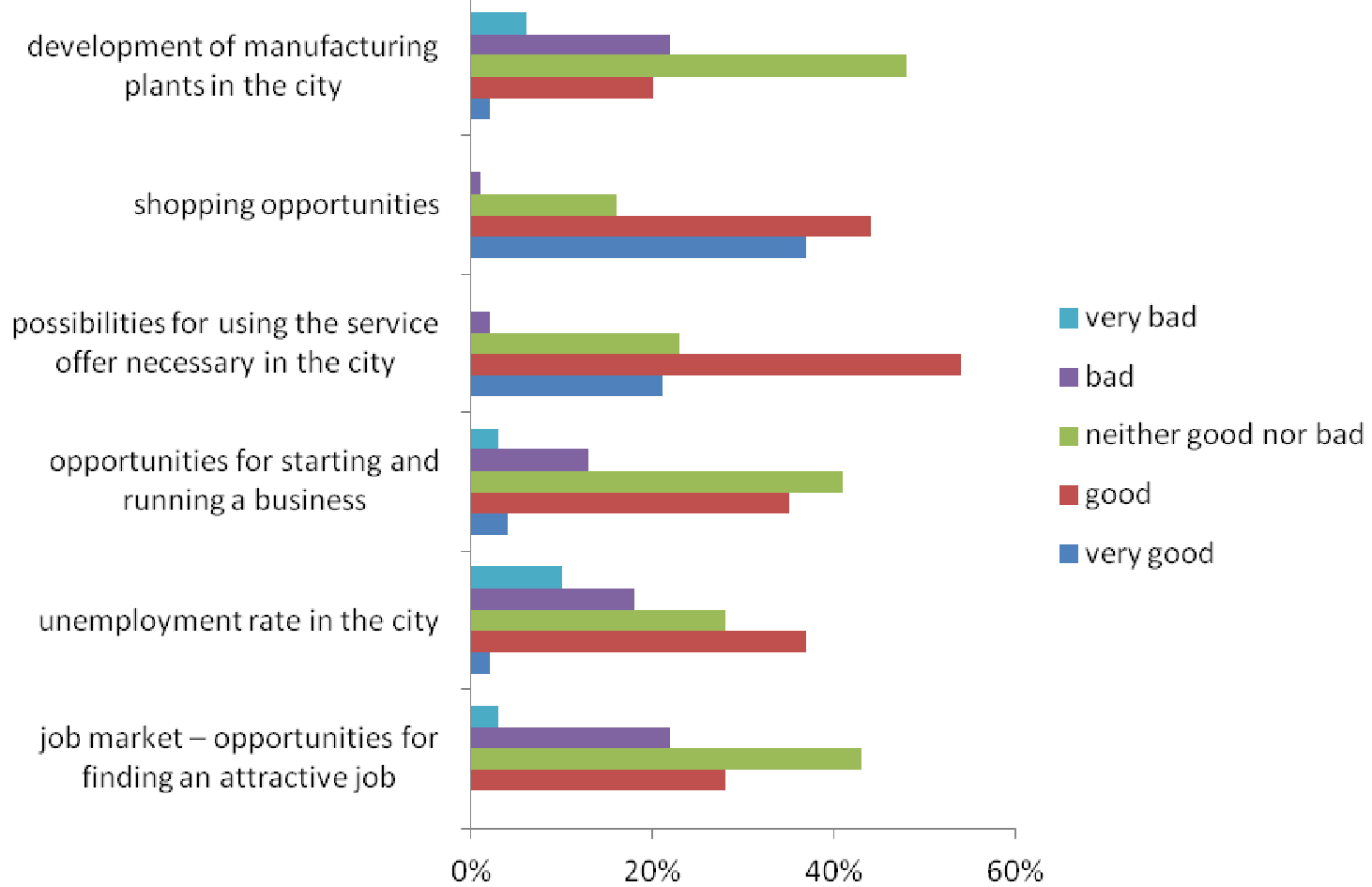

Fig. 5 - Economy - functional area assessment. Source: author's survey. 


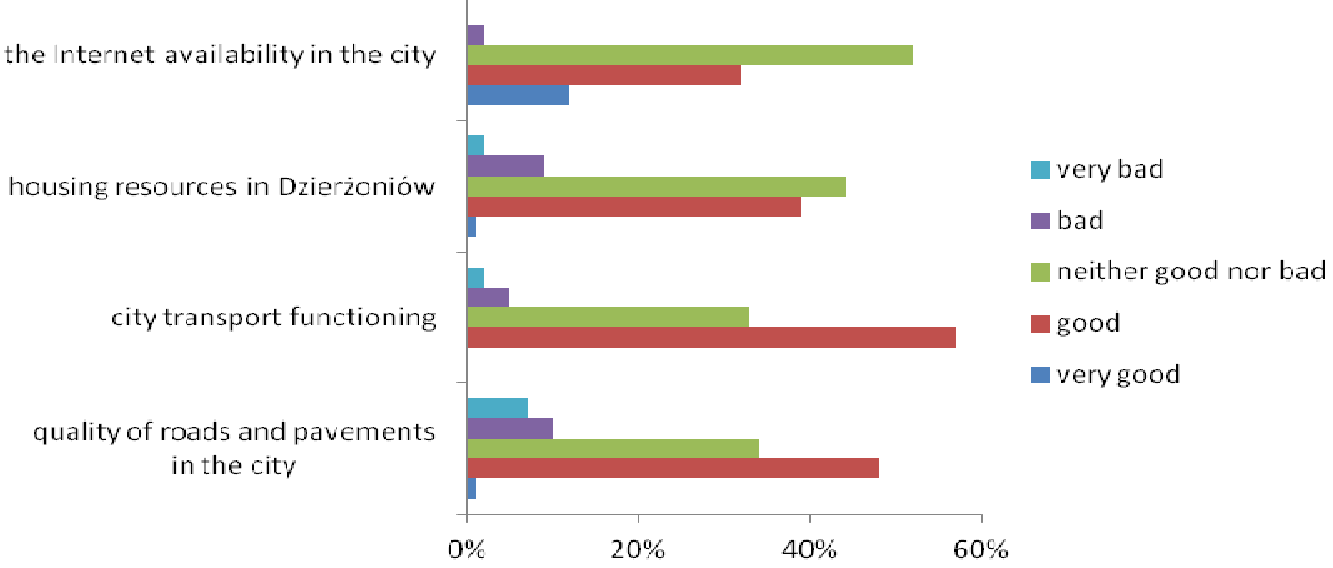

Fig. 6 - Technical infrastructure - functional area assessment. Source: author's survey.

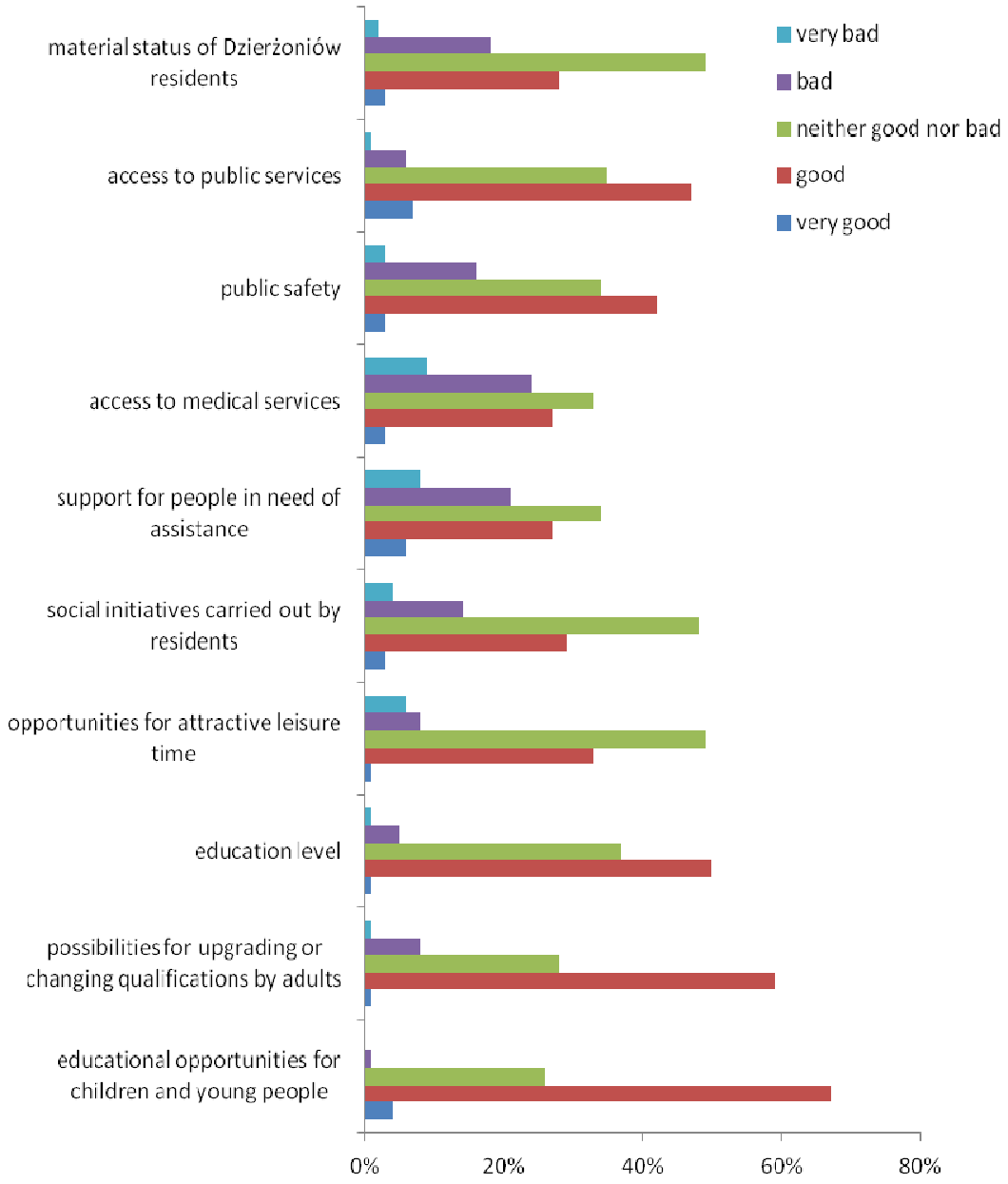

Fig. 7 - Social infrastructure - functional area assessment. Source: author's survey. 


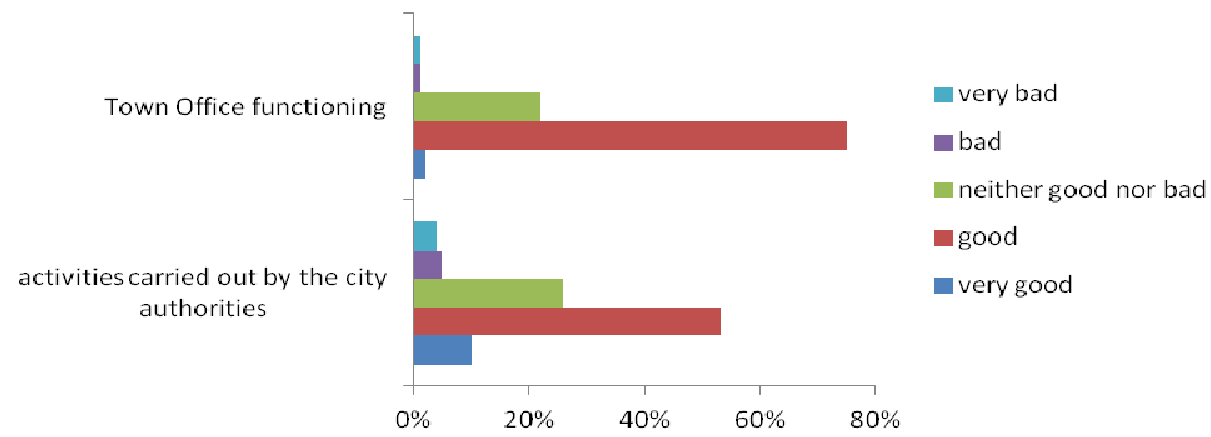

Fig. 8 - City management - functional area assessment. Source: author's survey.

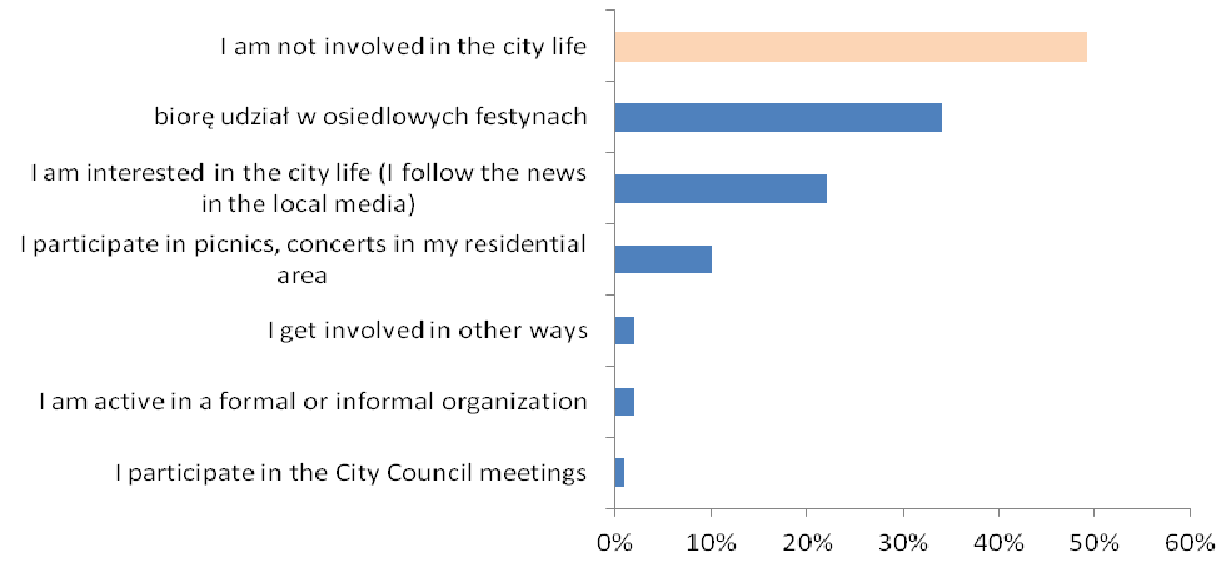

Fig. 9 - Residents' involvement in the city life (more than one answer possible). Source: author's survey.

At the same time the residents do not express any explicit standpoint in terms of their influence on the processes occurring in their town, $58 \%$ of the respondents do not have any clear opinion in this matter (Fig. 10). 6\% of the respondents observe such influence, whereas $32 \%$ present a different opinion. The above results confirm the need for bigger involvement in this matter and carrying out projects increasing the participation and activity of local community. The reasons of limited social activity result from several factors among which the following can be listed: reduced sense of possibility for co-deciding about the development of one's place of residence, relatively low confidence in political and business elites, focusing on supporting the family and also a difficult material situation experienced by some social groups.

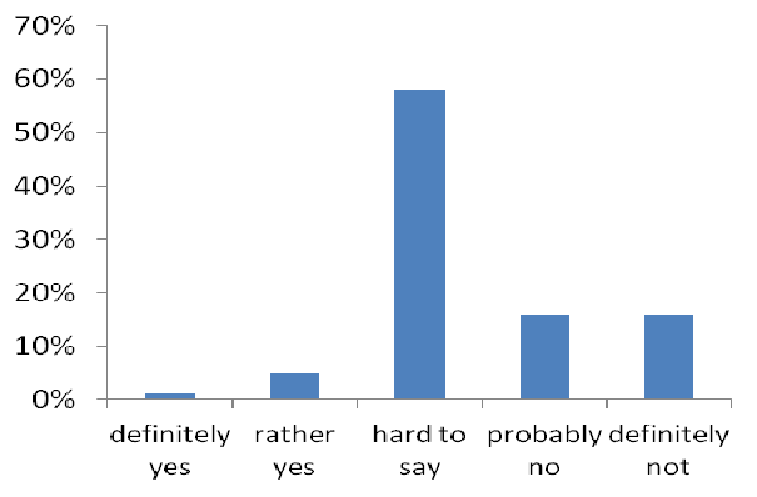

Fig. 10 - Do you have any influence, in your opinion, on what is happening in the city? Source: author's survey. 
The majority of positive responses were given by the surveyed residents, since as many as $50 \%$ of them expressed their satisfaction from the fact that they reside in Dzierżoniów (against only 12\% of the dissatisfied ones) (Figs. 11 and 12). 59\% of the respondents do not plan to move to another location. It is considered by $8 \%$ of the city residents. At the same time $32 \%$ of the surveyed participants would recommend Dzierżoniów as the place for living, whereas $10 \%$ of them are of an opposite opinion, along with $53 \%$ undecided in this matter. It proves that in spite of some problems and imperfections Dzierzioniów is generally perceived as a relatively friendly city for its residents and a good place for living (Fig. 13). The diagnosis of all weaknesses, threats and problems was focused on attempting to offer an ongoing improvement of the existing public services and to take up efforts aimed at better city management.

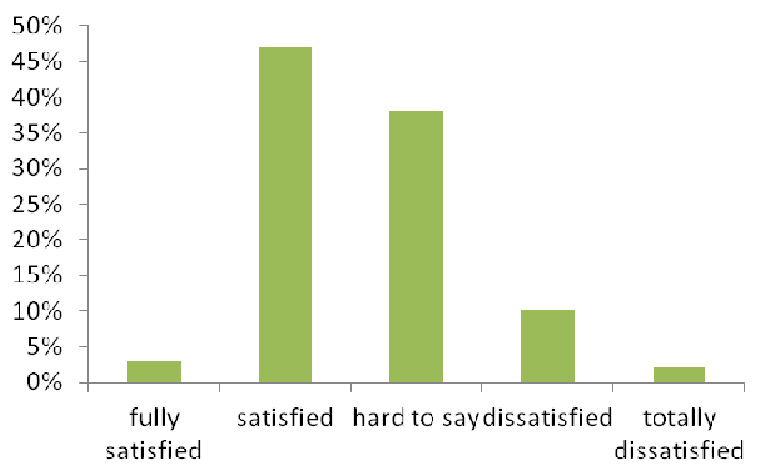

Fig. 11 - Are you satisfied with the fact that you are Dzierżoniów's resident? Source: author's survey.

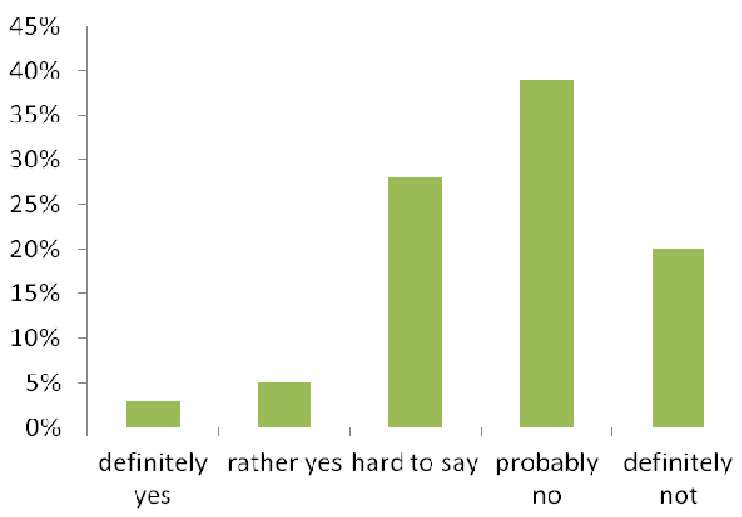

Fig. 12 - Do you plan to move to another location in the future? Source: author's survey.

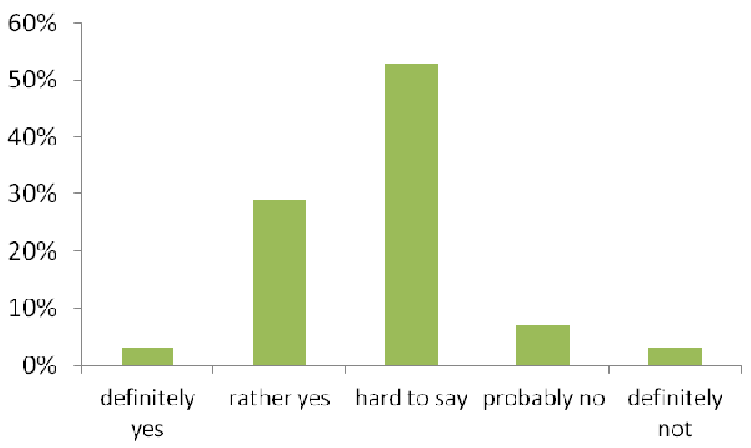

Fig. 13 - Would you recommend Dzierżoniów to others as the place for residence? Source: author's survey.

\section{Conclusions}

Within the framework of conducted studies the residents were also asked to identify these activities which, in their opinion, can bring the best results for Dzierżoniów's development in the years to come. The following indications were made:

- opening new jobs, unemployment rate reduction,

- road infrastructure improvement (ring road),

- development of parks, playgrounds, green areas,

- creating places for active leisure time spending,

- better public communication (service quality and network of connections),

- tourist and recreation infrastructure improvement (bike paths), better sport facilities (stadium renovation),

- support for SME sector (grants for starting a business),

- organization of mass events (more concerts, festivals),

- improvement of health care and medical services,

- technical infrastructure improvement (necessary renovations),

- better cleanliness and aesthetics of the city,

- more intensive city and its tourism potential promotion (locally and regionally),

- renovation of municipal buildings,

- social housing construction,

- new car parks, renovation of pavements, more garbage bins,

- better public safety (city lights, monitoring, more frequent police and city guard patrols),

- better educational offer in the city, additional courses and trainings, 
- development of commercial network (entertainment centre),

- support for innovative projects (cooperation with universities),

- free Internet in the city,

- counteracting social exclusions,

- better customer service quality in state administration institutions,

- better cultural offer (cinemas),

- facilities for the disabled,

- renovation of schools, more kindergartens,

- city centre revival and more diversified gastronomy offer.

A large number and diversification of the suggested projects indicate the residents' good awareness of their city developmental problems. It is also a valuable source of information in terms of endogenous initiatives. With regard to the fundamental research results presented in the study a general conclusion can be put forward about a relatively good assessment of Dzierżoniów presented by its residents. The largest imperfections and thus the areas requiring improvement were identified as the city cleanliness and order, the development of manufacturing plants in the city and the job market offer. Furthermore, the quality of roads and pavements was indicated as requiring improvement, as well as access to medical services or the support for those in need of assistance. Insufficient involvement of the city residents in its life seems to be a separate problem, along with the sense of limited influence on its functioning.

\section{References}

Blair J, Carroll M (2009) Local economic development. Analysis, practices and globalization. SAGE Publications, Thousand Oaks.

Clark G, Huxley J, Mountford D (2010) Organising local economic development: the role of development agencies and companies. OECD Publishing, Paris.

Hague C (2005) Planning and place identity. In: Hague $C$, Jenkins $P$ (eds) Place identity, participation and planning. Routledge, New York, pp. 3-18.

Klasik A (2002) Strategie regionalne. Formułowanie i wprowadzanie w życie. Wydawnictwo AE, Katowice.

Kornblum W (2011) Sociology in the Changing World. Cengage Learning, Andover.

Pike A, Rodriguez-Pose A, Tomaney J (2006) Local and Regional Development. Routledge, New York.

Raszkowski A (2013a) Strategia Zrównoważonego Rozwoju Lokalnego Dzierżoniowa na lata 2014-2020. Urząd Miasta w Dzierżoniowie, Dzierżoniów.

Raszkowski A (2013b) Diagnoza Dzierżoniowa oraz raport z badań ankietowych. Urząd Miasta w Dzierżoniowie, Dzierżoniów.

Raszkowski A (2013c) Raport z ewaluacji Strategii Zrównoważonego Rozwoju Lokalnego Dzierżoniowa za lata 2009-2012. Urząd Miasta w Dzierżoniowie, Dzierżoniów.

Raszkowski A (2014) Place marketing in the process of territorial identity creation and strengthening. Journal of European Economy 13(2): 193-204.

Strzelecki Z (2008 ed) Polityka regionalna, in: Gospodarka regionalna i lokalna. Wydawnictwo Naukowe PWN, Warszawa.

Yuan L, Yuen B, Low C (1999) Quality of Life in Cities Definition, Approaches and Research. In: Yuan L, Yuen $B$, Low C (eds) Urban quality of life. Critical issues and options, Singapore: School of Building and Real Estate, National University of Singapore, Singapore, pp. 1-12. 